\title{
PREVALENCE OF DICROCOELIUM DENDRITICUM INFECTION IN SHEEP AT TAIF PROVINCE, WEST SAUDI ARABIA
}

\author{
By \\ BANDAR M. ALBOGAMI ${ }^{1 *}$, ABDUL HAKEEM M. KELANY ${ }^{2}$ \\ AND OSAMA A. ABU-ZINADAH ${ }^{2}$ \\ Department of Biology, Faculty of Science, Taif University ${ }^{1}$, Department of Biological \\ Sciences, Faculty of Science, King Abdulaziz University ${ }^{2}$, Jeddah, Saudi Arabia \\ ( ${ }^{*}$ Correspondence author Email: bandaralbogami@gmail.com)
}

\begin{abstract}
Dicrocoelium dendriticum is a common zoonotic parasite of sheep in many Regions of Saudi Arabia. In chronic infections, this parasite causes biliary cirrhosis in livers of cattle, sheep, or goats and leads to economic losses. This study compared the prevalence of Dicrocoelium dendriticum in local sheep and imported sheep in Taif Province, West Saudi Arabia. This cross-sectional survey was carried out in slaughterhouses in Taif Province. A total 2230 local sheep and 21383 imported sheep were studied. The number of injury in imported sheep was observed as 99 representing $0.46 \%$ of the number of animals examined, while no record of any injury was observed in local sheep.

Key words: Saudi Arabia, Dicrocoelium dendriticum, local sheep, imported sheep, liver infection.
\end{abstract}

\section{Introduction}

D. dendriticum or the lancet liver fluke is a parasite of the bile ducts and gall bladder of worldwide distribution among more than sixty mammalian hosts (Mas-Coma and Bargues, 1997). However, sheep, cattle and other ruminants are the true definitive hosts and the other definitive hosts including man are more or less mere alternative hosts. The human clinical symptoms of true infection are neither uniform nor specific (Wilson, 1991). D. dendriticum with $D$. hospes as being long and narrow, are generally confined to the more distal parts of the bile ducts. As a result most $D$. dendriticum infections of the biliary tree produce only mild symptoms. In the initial stages, there is leukocytosis, eosinophilia and traces of bile acids in the urine. On further infection, slight anaemia may ensue, the leukocytosis drops to normal level and eosinophila diminishes to $5 \%-7 \%$ (Rosicky and Groschaft, 1982). Usually, the dicrocoeliasis is accompanied by either a prolonged period of constipation or diarrhea, nausea and vomiting. Sometimes, patients may complain of abdominal discomfort and pain in the right half of the abdomen and in the epigastrium radiating to right shoulder and chronic watery diarrhea with slight ele- vation of liver function tests (Cengiz et al. 2010). Additionally, Manga-González et al. (2004) reported significant increases in hepatic enzyme activity (ALT \& AST), which they suspected was a pathogenic response to parasite invasion which produces host-toxic metabolites. Sometimes, infection is accompanied by lassitude, headache and giddiness. Pain in the liver is continuous, independent of the uptake of food, and intensifies mainly at night (Price and Child, 1971).

Generally, parasitosis is regarded as an important health problem of grazing animals in Saudi Arabia, with losses associated with nematode and trematode infection approximating a million dollars (Mcleod, 1995). Reproductive disorders and parasitic infestation are the main problems that affecting productivity and cause great economic losses in farm animals (El-Khadrawy et al, 2008). Parasitic liver infections in meat producing animals are one of the major factors that reduce the national income and cause economic losses in this country (Radostits et $a l, 2007)$, either directly by their effect on animal growth and so meat production, or indirectly by affecting their reproduction (Senlik, et al, 2008). It has been found that parasitic helminthes are one of the most de- 
structive internal parasites of vertebrate animals including man (Strickland, 2000).

Sheep received great interest as one of the most important livestock for human consumption in in all Arab Countries, especially the Gulf.

The aim of this study was to raise awareness of the zoonotic Dicrocoelium dendriticum and its pathogenicity by clarifying the histopathological changes by TEM.

\section{Materials and Methods}

The two slaughterhouse certified by Taif Municipality were explored for the survey.

Table 1: technique of worm preparation

\begin{tabular}{|l|l|l|}
\hline \multicolumn{1}{|c|}{ Process } & \multicolumn{1}{|c|}{ Material } & \multicolumn{1}{c|}{ Duration } \\
\hline 1st Fixation & $2.5 \%$ Glutaraldehyde (0.2 M phosphate buffer, pH 7.4) & $2 \mathrm{~h}$ \\
\hline Washing & Phosphate buffer wash & $3 \times 15$ minutes each \\
\hline 2nd Fixation & $1 \%$ OsO4 (buffered as above) & $2 \mathrm{~h}$ \\
\hline Washing & Phosphate buffer wash & $3 \times 15$ minutes each \\
\hline Dehydration & Ascending series of Ethanol & $1 \times 15$ minutes each \\
\hline Infiltration & Acetone & $1 \mathrm{hr}$. \\
\hline & Acetone : 1resin & $2 \times 1$ hr. each \\
\hline Embedding & Pure resin & $1 \mathrm{hr}$ \\
\hline Blocks polymerization & Oven at $60^{\circ} \mathrm{C}$ & 3 days \\
\hline Cutting & $\begin{array}{l}\text { Ultrathin sectioning 60-90nm \& gold on copper grids by ultra-microtome Leica } \\
\text { model EM UC }\end{array}$ \\
\hline Contrasting & $\begin{array}{l}\text { Tissues held on copper grids stained by Uranyl acetate and lead citrate (15 } \\
\text { minutes r each). }\end{array}$ \\
\hline Examination & By Transmission Electron Microscope model Jeol JEM 1011 \\
\hline
\end{tabular}

\section{Results}

The results are shown in table (2) and figures (1 to 9)

Table 2: Statistics of local and imported infected sheep

\begin{tabular}{|l|c|c|c|}
\hline \multicolumn{1}{|c|}{ Month } & Total Number Imported & Total Number infection & Percentage of infection \\
\hline November 2013 & 1482 & 5 & 0.33 \\
\hline December & 1104 & 3 & 0.27 \\
\hline January 2014 & 1506 & 4 & 0.26 \\
\hline February & 1413 & 7 & 0.49 \\
\hline March & 1431 & 6 & 0.41 \\
\hline April & 1392 & 3 & 0.21 \\
\hline May & 1446 & 8 & 0.55 \\
\hline June & 1927 & 10 & 0.51 \\
\hline July & 1212 & 4 & 0.33 \\
\hline August & 1430 & 6 & 0.41 \\
\hline September & 1311 & 11 & 0.83 \\
\hline October & 1621 & 21 & 1.29 \\
\hline November & 1456 & 5 & 0.34 \\
\hline December & 996 & 4 & 0.40 \\
\hline January 2015 & 1656 & 2 & 0.12 \\
\hline
\end{tabular}




\section{Discussion}

In the present study, infection with Dicrocoelium dendriticum in sheep was all over the study period. The infection rate was changes between up and down There was marked increase in February followed by slight drop, then marked increase in May followed by slight drop. The infection rate increased again in September with a higher raise in October.

In the present study, the hyperplastic Kupffer phagocytic cells with numerous vacuoles and dense granules in cytoplasm (Figs. $3 \& 4$ ) also clearly visible with lower magnifications (X2500). Also, transmission electron micrographs $(\mathrm{X} 10,000)$ showed hyperplasia in Kupffer cells with multiple cytoplasmic fat vacuoles scattered between cells (Fig. 5).

These caused indentations in the nuclei on the periphery against the cell membranes resulting in a signet ring appearance. Other histo-pathological abnormalities in infested hepatocytes revealed dense granular vesicular cytoplasm. Portal tract granuloma were seen constituting lymphoplasmocytes, histiocytes, foreign body giant cells and fibroblasts all surrounding the parasite (Fig. 6).

Moreover, the infected sheep livers demonstrated disarrayed hepatocytes with cytoplasm of different-sized black bodies (Fig. 7), the vacuolization and compressed blood sinusoids. The infected hepatocytes also showed cytoplasmic granules as well as scattered phagocytes and blood sinusoids in between cells containing proteinaceous material in addition to blood cells (Fig. 8).

Dicrocoelium dendriticum infection increased blood proteins, but Theodoridis et al. (1991) reported that the presence of up to 4000 worms in the host did not cause significant protein loss, thus not a serious threat. The extremely low numbers of Dicrocoeli$u m$ reported in the present study had no serious effect on the sheep and apart from their pathological effect in the liver, had no effect on the economy.
In the present study, although infection was low in Taif Province and pathological symptoms were quite conspicuous, rendering them unsellable. Lesions and/or ulcers were the main reason for discarding all the infected sheep livers.

The most serious sign of Dicrocoelium infection was reduced weight in the early stages of infection, development of anemia, oedemas and reduction in production (Broglia et al, 2009).

Dicrocoeliasis was endemic or potentially endemic in 30 countries. D. dendriticum was found throughout Europe (former U.S.S.R., Switzerland, Italy, Germany, Spain, and Turkey), the Middle East (Iran, Saudi Arabia, Kuwait, Lebanon and Syria), Asia (China, Japan, and Vietnam), and Africa (Ghana, Nigeria, Sierra Leone, and Somalia) and in North and South America and Australia (Stancampiano et al. 2007). Human infection ranged between one patient in USA (Drabik et al. 1988) up to 208 patients in Saudi Arabia (el-Shiekh Mohamed and Mummery, 1990). WHO (2007) included D. dendriticum on its list of organisms to target with its Food-borne Disease Burden Epidemiology Reference Group.

In Arab Countries, infections in man and/ or animals have been reported in Egypt (Scheid et al, 1950; Massoud et al, 2003; Haridy et al, 2003; 2006; El-Shafie et al, 2011), Iraq (Wajdi and Nassir, 1983), Lebanon and Syria (Yenikomshian and Berberian, 1934; Tohmé and Tohmé, 1977; Khalil et al, 2013), Kuwait (Al Behbehani et al, 2003), Somalia (Nødgaard and Kristensen, 1995), and in Sudan (Sabbatani and Fiorino, 2009).

On the other hand, in Saudi Arabia many authors reported the zoonotic dicrocoeliasis (Nasher, 1990; Omar et al. 1991; Gawish et al, 1993; Abu Zinada, 1999; Helmy and Al Mathal, 2003; Al-Mathal and Fouad, 2004; Al-Megrin, 2010; Mohammad and Koshak, 2011). 


\section{Conclusion}

Dicrocoeliasis (Lancet liver fluke disease) is caused by $D$. dendriticum, a trematode living in bile ducts of sheep, cattle and other mammals including man. Human and animal infections have been world widely reported particularly in some of the Eastern Mediterranean sheep raising countries. The life cycle proceeds through two intermediate hosts: the land snail and the field ant. Zoonotic transmission could occur through the sheep, buffalo, deer and/or donkey. Human infection is acquired by consuming 17 species of field ant with raw fruits, vegetables, herbs or even with the drinking water. Human infection is asymptomatic or mild to moderately severe, but being sporadic or rarely reported. Basically, the public health workers and medical veterinarians must keep in mind zoonotic parasitosis such as the encountered and underestimated dicrocoeliasis.

\section{References}

Abu Zinada, NY, 1999: Natural dicrocoeliasis in imported sheep, Jeddah, Saudi Arabia. J. Egypt. Soc. Parasitol. 29, 2:649-52.

Al-Behbehani, B, Mathew, TC, Dashti, HM, 2003: Ultrastructural studies on the tegument of Dicrocoelium dendritium Looss 1899. J. Egypt. Soc. Parasitol. 33, 1:31-40.

Al-Mathal, EM, Fouad, MA, 2004: Myrrh (Commiphora molmol) in treatment of human and sheep dicrocoeliasis dendriticum in Saudi Arabia. J. Egypt. Soc. Parasitol. 34, 2: 713-20.

Al-Megrin, WA, 2010: Intestinal parasites infection among immunocompromised patients in Riyadh, Saudi Arabia. Pak. J. Biol. Sci. 13, 8: 390-4.

Broglia, A, Heidrich, J, Lanfranchi, P, Nöckler, K, Schuster, R, 2009: Experimental ELISA for diagnosis of ovine dicrocoeliosis and application in a field survey. Parasitol. Res. 104, 4: 949-53.

Cengiz, ZT, Yilmaz, H, Dulger, A, et al, 2010: Human infection with Dicrocoelium dend-riticum in Turkey. Ann. Saudi Med. 30, 2:159-61.

Drabik, JJ, Egan, JE, Brown, SL, Vick, RG, Sandman, BM, et al, 1988: Dicrocoeliasis (lancet fluke disease) in an HIV seropositive man. J. Amer. Med. Assoc. 259, 4:567-8.

El-Khadrawy HH, El Moghazy FM, Abd El
Aziz MM, Ahmed, WM, 2008: Field investigation on the correlation between ovarian activity and fascioliosis in buffalo-cows American-Eurasian. J. Agric. Environ. Sci. 3, 4:539-46.

El-Shiekh Mohamed, A, Mummery, V, 1990: Human dicrocoeliasis: Report on 208 cases from Saudi Arabia. Trop. Geogr. Med. 42, 1: 1-7.

El-Shafie, AM, Fouad, MAH, Khalil, MF, Morsy, TA, 2011: Zoonotic dicrocoeliasis dendriticum in a farmer's family at Giza Governorate, Egypt. J. Egypt. Soc. Parasitol. 41, 2: 327-36

Gawish, NI, Bayoumi, B, Haridy, FM, 1993: Studies on the incidence and pathogenesis of Dicrocoelium dendriticum in slaughtered sheep in Riyadh abattoir, Saudi Arabia. J. Egypt. Soc. Parasitol. 23, 1:263-7.

Haridy, FM, El-Sherbiny, GT, Morsy, TA, 2006: Some parasitic flukes infecting farm animals in Al-Santa Center, Gharbia Governorate, Egypt. J. Egypt. Soc. Parasitol. 36, 1:259-64

Haridy, FM, Morsy, TA, Ibrahim, BB, AbdelAziz, A, 2003: A preliminary study on dicrocoeliasis in Egypt, with a general review. J. Egypt. Soc. Parasitol. 33, 1:85-96.

Helmy, MMF, Al-Mathal, EM, 2003: Human infection with Dicrocoelium dendriticum in Riyadh district (Saudi Arabia). J. Egypt. Soc. Parasitol. 33, 1:139-44.

Khalil, G, Haddad, C, Otrock, ZK, Jaber, F, Farra, A, 2013: Halzoun, an allergic pharyngitis syndrome in Lebanon: the trematode Dicrocoelium dendriticum as an additional cause. Acta Trop. 125, 1:115-8

Manga-González, MY, Ferreras, M, Campo, R, González, LC, et al. 2004: Hepatic marker enzymes, biochemical parameters \& pathological effects in lambs experimentally infected with D. dendriticum (Digenea). Parasitol. Res. 93, 5: 344-55.

Mas-Coma, S, Bargues, MD, 1997: Human Liver flukes: a review. Res. Rev. Parasitol. 57, 3/4: 171-212.

Massoud, A, Morsy, TA, Haridy, FM, 2003: Treatment of Egyptian dicrocoeliasis in man and animals with Mirazid. J. Egypt. Soc. Parasitol. 33, 2:437-42.

McLeod, RS, 1995: Cost of major parasites to the Australian livestock industries. Int. J. Parasitol. 25:1363-17.

Mohammad KHA, Koshak, EA, 2011: A prospective study on parasites among expatriate wo- 
rkers in Al-Baha from 2009-2011, Saudi Arabia. J. Egypt. Soc. Parasitol., 41, 2:327-36

Nasher, AK, 1990: Parasites of livestock in Asir Province, southwestern Saudi Arabia. Vet. Parasitol. 37, 3/4:297-300.

Nødgaard, H, Kristensen, B, 1995: Dicrocoelium dendriticum egg in feces of 2 Somali boys in Denmark: Transitory elimination after arrival to Denmark. Ugeskr. Laeger. 157, 29:4140-6.

Omar, MS, Abu-Zeid, HA, Mahfouz, AA, 1991: Intestinal parasitic infections in schoolchildren of Abha (Asir), Saudi Arabia. Acta Trop. 48, 3:195-202.

Price, DL, Child, P, 1971: Dicrocoeliasis (Distomiasis) In: Pathology of Protozoal \& Helminthic Diseases with Clinical Correlations. By: R A, Marcial-Rojas, Williams and Wilkins, Baltimore, USA.

Radostits, OM, Gay, CC, Hinchcliff, KW, et al, 2007: Veterinary Medicine: A Textbook of The Diseases of Cattle, Horses, Sheep, Pigs, and Goats. $10^{\text {th }}$ ed. Philadelphia: Saunders.

Rosicky, B, Groschaft, J, 1982: Dicrocoeliasis. In: Handbook Series in Zoonoses: Parasitic Zoonoses. V. 3 (G.V. Hillyer \& C.E. Holpa, eds), CRC Press, Boca Raton, Florida.

Sabbatani, S, Fiorino, S, 2009: Contribution of palaeopathology to defining the pathocoenosis of infectious diseases: (Part 2). Infez. Med. 17, 1:47-63.

Scheid, G, Mendheim, H, Amenda, R, 1950: Die Lanzetegel infection (Dicrocoeliasis) beim, Menschen nebst Mitteilung eines neuen Falles. Zeitschrift Tropenmed. Parasitol. 2:142-7

Senlik, B, Cirak, VY, Karabacak, A, 2006: Intestinal nematode infections in Turkish military dogs with special reference to Toxocara canis. J. Helminthol. 80:299-303.

Stancampiano, L, Corradini, D, Bulgarelli, M, Micagni, G, 2007: Parasites of the digestive tract in beef cattle imported from France to Italy. Parassitol. 49, 1/2:101-6.

Strickland, GT, 2000: Hunter's Tropical Medicine and Emerging Infectious Diseases. $8^{\text {th }}$ ed. W.B. Saunders Company, Philadelphia, London, Toronto, Montreal, Sydney, Tokyo.

Theodoridis, Y, Duncan, JL, MacLean, JM, Himonas, CA, 1991: Pathophysiological studies on Dicrocoelium dendriticum infection in sheep. Vet. Parasitol. 39, 7:61-6.

Tohmé, H, Tohmé, G, 1977: Intermediary hosts of Dicrocoelium lanceolatum in Lebanon \& Syria. Ann. Parasit. Hum. Comp. 52, 2:1-5
Wajdi, N, Nassir, JK, 1983: Studies on the parasitic helminths of slaughtered animals in Iraq. Parasitic helminthes of the liver of herbivores. Ann. Trop. Med. Parasitol. 77, 6:583-5.

WHO, 1995: WHO Model Prescribing Information: Drugs Used in Parasitic Diseases. $2^{\text {nd }}$ ed. Wilson, ME, 1991: A World Guide to Infections: Diseases, Distribution, Diagnosis. New York, Oxford University Press.

Yenkomshian, HA, Berberian, DA, 1934: The occurrence and distribution of human helminthiasis in Syria and Lebanon, with case reports on Dicrocoelium dendriticum \& Hymenolepis nana infestations. Trans. R. Soc. Trop. Med. Hyg. 27: 425-31.

\section{Explanation of figures}

Fig. 1: Rate of injuries /month among study period. Fig. 2: Ovine liver infected with Dicrocoelium dendriticum. Parenchyma hardened as a result of severe fibrosis and calcification (deformities in cellular and tissue structure), thickened ducts (A), and worms in tissue (B). Scale bar $=5 \mathrm{~cm}$.

Fig. 3: Parasite causing (A) multiple cytoplasmic electron dense globules (blue); (B) pushing and indenting nuclei (red); to periphery against cell membrane (E/M x8000).

Fig. 4: Parasitic infection indicated by (A) hyperplastic dense granule (upper left) (green) in cytoplasm (E/M x8000)

Fig. 5: Parasitic infection causing (A) Kupffer cell proliferation (red); and (B) multiple cytoplasmic electron dense granule (oranges) pushing nuclei to periphery against cell membrane (E/M, x2500).

Fig. 6: Parasitic infection causing (A) Kupffer cell hyperplasia (oranges); with (B) multiple cytoplasmic fat globules (blue); pushing (C) indent nuclei to periphery against cell membrane (red); giving signet ring appearance $(\mathrm{E} / \mathrm{M}, \mathrm{x} 10,000)$.

F. 7: Parasitic infection with proliferated Kupffer cells and (A) hepatocytes possessing a granular vesicular cytoplasm(oranges); (B) portal tract granuloma (Red ); formed by lymphoplasmocytes, histiocytes, foreign body giant cells and fibroblasts around parasite (Toluidine blue x 200).

Fig. 8: Infected disarrayed hepatocytes containing (A) cytoplasmic parasitic variable sized blackish bodies (red); and reveal (B) vacuolated granular cytoplasm. Blood sinusoids compressed (oranges). Toluidine blue $\mathrm{x} 200$.

Fig. 9: Infected (A) hepatocytes that contain cytoplasmic granules (yellow); and (B) centrally placed nuclei (oranges). Also, scattered phagocytic cells, blood sinusoids in between infected hepatocytes (C) compressed and contain blood cells and proteinaceous aterial (red); Toluidine blue, $\mathrm{x} 200$. 

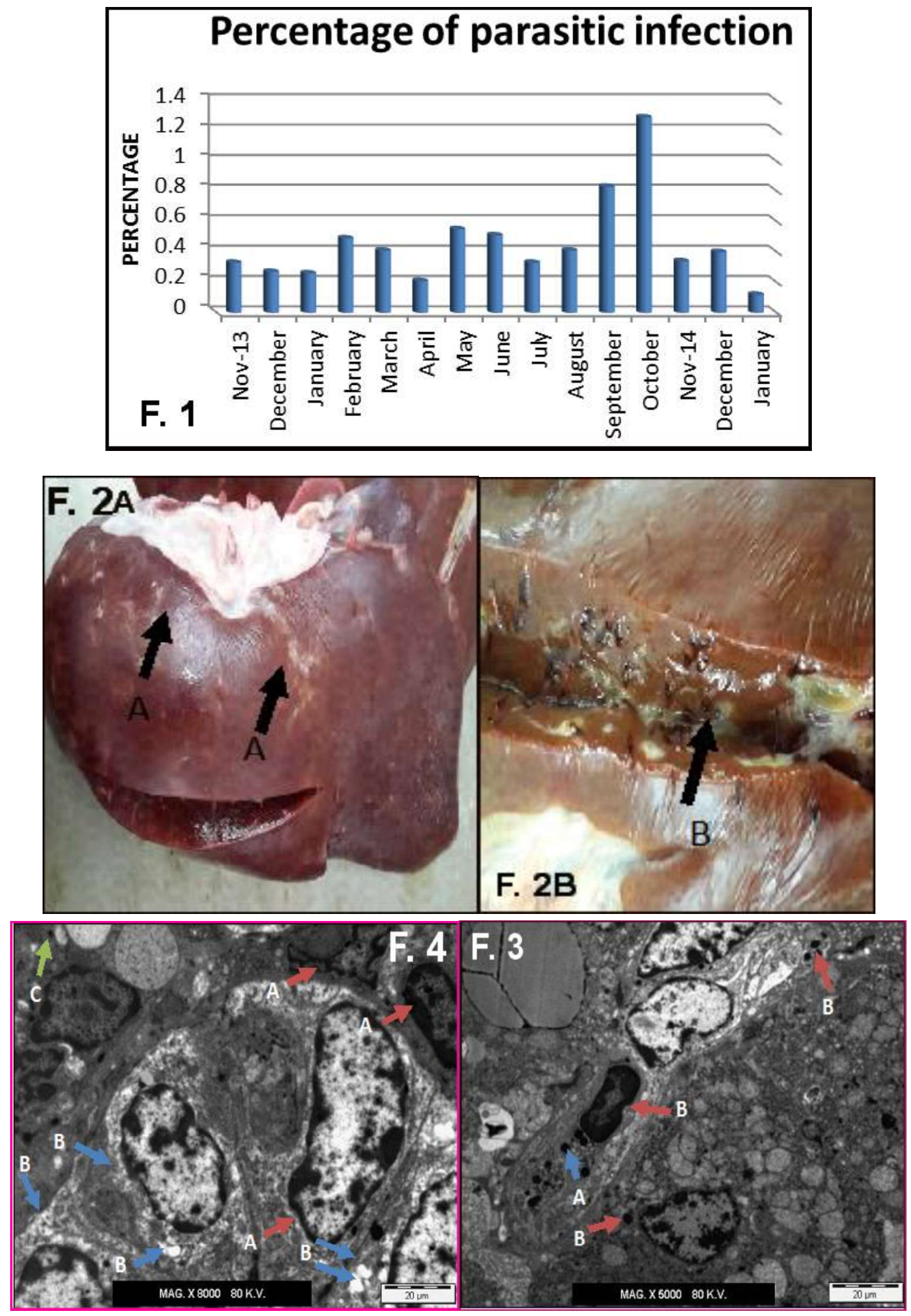


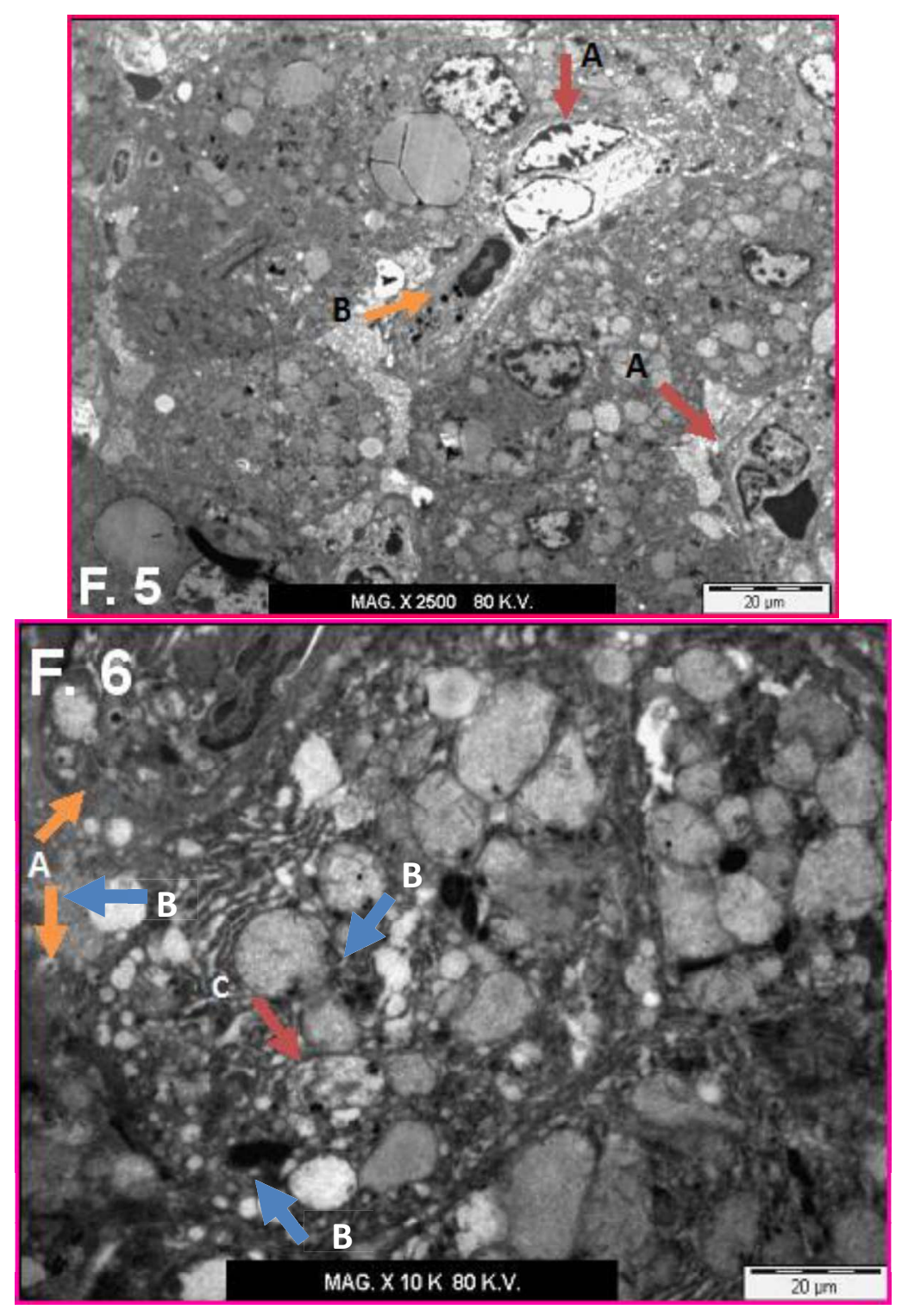




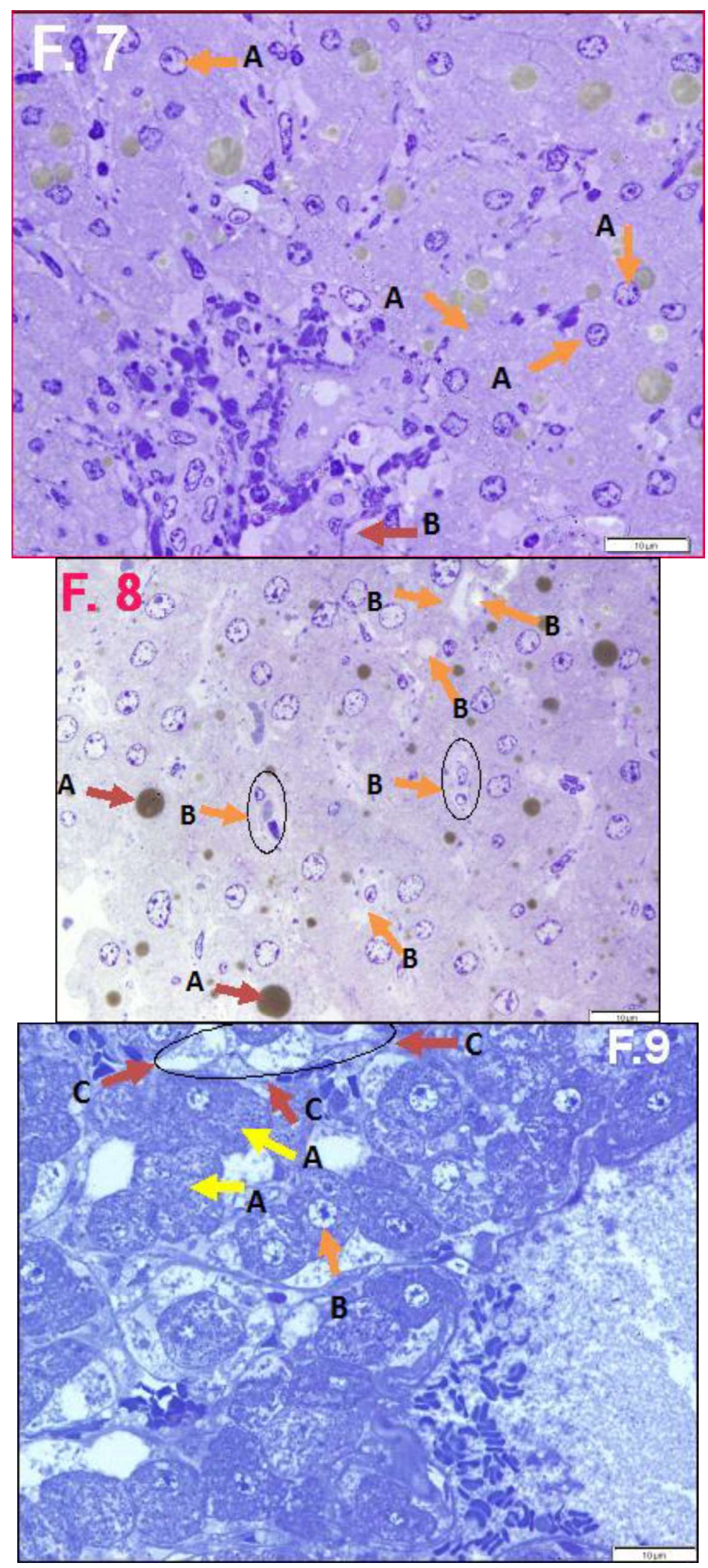

